\title{
Penegakan Hukum Pada Kasus Tindak Pidana Kecelakaan Lalu Lintas Yang Menyebabkan Hilangnya Nyawa Orang
}

\author{
Muhammad Dani Hamzah \\ * Mahasiswa Program Magister Ilmu Hukum, Program Pasca Sarjana Universitas Islam Sultan Agung, \\ Semarang, Pegawai BUMN (PT. KAI), Email: dani07hamzah@gmail
}

\begin{abstract}
ABSTACT
Equality before the law is an important principle in modern law, which is one of the joints of Rule of Law doctrine in a developing country like Indonesia, so this principle is used as the basis for every human being in enforcing the law. Increased traffic activity triggers an increase in traffic-related issues, one of which is a traffic accident. The problem is that it is difficult to provide law enforcement that can lead to a deterrent effect resulting in traffic awareness. The purpose of this study is to review criminal law enforcement in terms of legislation and review accountability in cases of criminal acts of traffic accidents that result in the loss of life of people in the traffic accident crime in Semarang City. Types of normative juridical research. The nature of the research using descriptive qualitative. Techniques of collecting data using secondary data (verdict number 599 / Pid.Sus / 2017 / PN.Smg and number 625 / Pid.B / 2017 / PN.Smg.). The results indicate that criminal law enforcement of traffic accidents resulting in the loss of life of persons still has some weaknesses and for accountability the crime has fulfilled the element of criminal liability in general.
\end{abstract}

Keywords: law enforcement, criminal acts, accidents, traffic

\begin{abstract}
ABSTRAK
Equality before the law merupakan salah satu asas penting dalam hukum modern, dimana ini menjadi salah satu sendi doktrin Rule of Law yang di negara berkembang seperti Indonesia, sehingga asas ini dijadikan landasan oleh setiap manusia dalam melakukan penegakan hukum. Makin meningkatnya aktivitas lalu lintas memicu peningkatan masalah yang berhubungan dengan lalu lintas, salah satunya dalah kecelakaan lalu lintas. Masalahnya adalah sulit dalam memberikan penegakan hukum yang dapat menimbulkan efek jera sehingga timbul kesadaran berlalu lintas. Tujuan dalam studi ini adalah untuk meninjau penegakan hukum pidana yang ditinjau dari perundang-undangan dan meninjau pertanggungjawaban pada kasus tindak pidana kecelakaan lalu lintas yang menyebabkan hilangnya nyawa orang pada tindak pidana kecelakaan lalu lintas di Kota Semarang. Jenis penelitian yuridis normatif. Sifat penelitian menggunakan deskriptif kualitatif. Teknik pengumpulan data menggunakan data sekunder (putusan nomor 599/Pid.Sus/2017/PN.Smg dan nomor 625/Pid.B/2017/PN.Smg.). Hasil menujukkkan bahwa penegakan hukum pidana kecelakaan lalu lintas yang mengakibatkan hilangnya nyawa orang masih memeiliki beberapa kelemahan dan untuk pertanggungjawaban pidanya telah memnuhi unsur pertanggungjawaban pidana secara umum.
\end{abstract}

Kata kunci: penegakan hukum, tindak pidana, kecelakaan, lalu lintas

\section{PENDAHULUAN}

Indonesia dalah negara hukum yang memiliki atukan hukum yang bersifat memakas bagi setiap masyarakat yang tinggal di Indonesia. Sebagai negara hukum Indonesia berdasar atas hukum bukan 
hanya kekuasaan semata, sehingga di Indonesia kedudukan hukum berada pada posisi tertinggi (supremasi hukum/ rule of law). Equality before the law merupakan salah satu asas penting dalam hukum modern, dimana ini menjadi salah satu sendi doktrin Rule of Law yang di negara berkembang seperti Indonesia, sehingga asas ini dijadikan landasan oleh setiap manusia dalam melakukan penegakan hukum.

Penegakan hukum yang ada di masyarakat modern tidak hanya diartikan dalam arti sempit tetapi juga dalam arti luas, seperti di Indonesia penegakan hukum dikaitkan dengan unsur manusia dan lingkungan sosialnya. ${ }^{1}$ Usaha penegakan hukum sejalan dengan prinsip NKRI yaitu Pancasila. Tegaknya hukum merupakan suatu prasyarat bagi sebuah negara hukum, penegakan hukum selalu melibatkan manusia-manusia di dalamnya dan dengan demikian akan melibatkan tingkah laku manusia juga. Upaya penegakan hukum pidana pada hakikatnya juga merupakan bagian dari usaha penegakan hukum dan sering dikatakan sebagai politik atau kebijakan hukum pidana yang merupakan bagian dari kebijakan penegakan hukum (law enforcement policy). ${ }^{2}$

Lalu lintas di Indonesia diatur dalam peraturan perundang-undangan yaitu Undang-Undang Nomor 22 tahun 2009 tentang Lalu Lintas dan Angkutan Jalan, dimana peraturan tersebut dibuat guna menjamin keamanan, ketertiban dan kesejahteraan dalam masyarakat yang perlu ditentukan mengenai tindakan yang dilarang dan diharuskan. Sedangkan pelanggaran dari ketentuan tersebut diancam dengan pidana. Sering terjadinya pelanggaran lalu lintas, baik yang disengaja maupun yang tidak disengaja mungkin disebabkan karena sanksi yang dijatuhkan kepada para pelaku pelanggaran lalu lintas tersebut terlalu ringan, maka tidak heran jika kian hari kian banyak terjadi peristiwa pelanggaran lalu lintas. Akibat hukum dari kecelakaan lalu lintas adalah adanya sanksi pidana bagi si pembuat atau penyebab terjadinya peristiwa itu dan dapat pula disertai tuntutan perdata atas kerugian material yang ditimbulkan.

Hingga September 2017, kasus lakalantas di Kota Semarang mencapai 722 kasus, dan diperkirakan ada sekitar 1,97 kecelakaan per hari. Sementara itu, di tahun 2016 tercatat ada 1.083 kasus kecelakaan lalu lintas atau setidaknya 2,96 kecelakaan per hari. Jumlah korban sekitar 223 orang meninggal dunia, 2 korban luka berat dan 1.111 korban luka ringan serta kerugian materiil hingga Rp 1,12 miliar. Data pada tahun 2017, tercatat ada 749 korban kecelakaan, 151 orang meninggal dunia, dua korban luka berat dan 596 luka ringan disamping kerugian materi sebesar Rp 700 juta. $^{3}$

Tingginya angka kecelakaan lalu lintas yang bannyak menelan korban jiwa yang paling banyak terjadi yang disebabkan oleh kecelakaan lalu lintas perlu penyelesain secara arif dan bijaksana. Tindak pidana kecelakaan lalulintas adalah jenis tindak pidana kealpaan, bukan kesengajaan. Hal ini bukan merupakan kejahatan, akan tetapi merupakan tindak pidana pelanggaran.

Pada tahun 2017 terdapat sekitar 9 putusan pengadilan terkait kasus pidana lalu lintas. ${ }^{4}$ Putusan yang dijatuhkan pada setiap kasus didasarkan pada pertimbangan lingkungan keluarga, lingkungan tempat tinggal, karakter, apakah pernah dihukum, apakah antara pelaku dengan korban ada penyelesaian secara kekeluargaan, dari semua fakta yang ada dikaitkan pada keyakinan hakim atau kesemuanya dikembalikan pada hati nurani hakim.

\footnotetext{
${ }^{1}$ Bambang Poernomo, Kapita Selekta Sistem Peradilan Pidana, Universitas Jayabaya, 2001, hal. 3.

2 Barda Nawawi Arief, Bunga Rampai Kebijakan Hukum Pidana, PT. Citra Aditya Abadi, Jakarta, 1996, hal. 29.

3 Deny Irwanto, Tahun 2017, Angka Kecelakaan Lalu Lintas di Kota Semarang Menurun, https://www.beritasemarang.net/tahun-2017-angka-kecelakaan-lalu-lintas-di-kota-semarang-menurun/4893/, diakses 3 Januari 2018

4 Mahkamah Agung RI, Direktori Putusan, https://putusan.mahkamahagung.go.id/pengadilan/pnsemarang/direktori/pidana-umum/lalu-lintas, diakses 3 Januari 2018
} 
Krisis keadilan dalam penyelenggaran peradilan di Indonesia terutama dalam penyelasaian perkara pidana menimbulkan banyak reaksi. Reaksi tersebut, ada yang secara hukum dibenarkan maupun yang tidak dibenarkan menurut hukum.

Permasalahan dalam penyelesaian perkara pidana lalu lintas adalah dilakukannya peradilan pidana oleh penegak hukum. Polisi melakukan penyidikan dan seterusnya dilakukan penuntutan dan pengadilan, sementara penyelesaiaaan yang telah dilakukan oleh pihak-pihak terkait dianggap bukan penyelesaian oleh sistem hukum positif dalam KUHP. Tidak banyak studi yang membahas terkait dengan penegakan hukum dalam kasus pidana kecelakaan lalu lintas, sehingga studi ini bertujuan untuk mengkaji penegakan hukum pidana yang ditinjau dari factor perundang-undangan dan mengkaji terkait dengan pertanggungjawaban pada kasus tindak pidana kecelakaan lalu lintas yang menyebabkan hilangnya nyawa orang pada tindak pidana kecelakaan lalu lintas di Kota Semarang.

\section{Metode Penelitian}

Lokasi penelitian di Kota Semarang. Jenis penelitian yuridis normatif. Sifat penelitian menggunakan deskriptif. Teknik pengumpulan data menggunakan studi kepustakaan. Teknik analisis data yang digunakan adalah analisis kualitatif dengan model interaktif yaitu data yang terkumpul akan dianalisa melalui tiga tahapan, yaitu mereduksi data, menyajikan data, dan kemudian akan tahap tersebut, sehingga data yang terkumpul berhubungan dengan data yang lainnya. ${ }^{5}$ Di dalam penelitian kualitatif proses analisis biasanya dilakukan secara bersamaan dengan proses pelaksanaan pengumpulan data. Tiga komponen utama yaitu reduksi data, penyajian data dan penarikan kesimpulan.

\section{HASIL PENELITIAN DAN PEMBAHASAN}

Putusan Pengadilan Negeri Semarang terkait kasus pidana lalu lintas tahun 2017, yaitu:

1. Putusan Pengadilan Negeri Semarang Nomor 599/Pid.Sus/2017/PN.Smg Tahun 2017

Majelis Hakim menjatuhkan putusan pidana pada kasus nomor 599/Pid.Sus/2017/PN.Smg, adalah sebagai berikut:

a. Menyatakan Terdakwa Haris Setyo Yunanto Bin Suhartono terbukti secara sah dan meyakinkan telah bersalah melakukan tindak pidana: Karena kelalaiannya menyebabkan kecelakaan Lalu Lintas mengakibatkan orang lain meninggal ".

b. Menjatuhkan pidana terhadap Terdakwa dengan pidana penjara selama : 5 ( lima ) bulan;

c. Menetapkan bahwa pidana penjara tersebut tidak usah dijalani kecuali dengan suatu perintah Hakim terdakwa telah dinyatakan terbukti bersalah melakukan suatu perbuatan pidana lain sebelum masa percobaan berakhir yang lamanya : 10 ( sepuluh ) bulan;

d. Menjatuhkan pidana denda kepada terdakwa sebesar Rp. 2.000.000,- (dua juta rupiah) dengan ketentuan jika denda tersebut tidak dibayar harus diganti dengan pidana penjara selama 1 (satu) bulan ;

e. Memerintahkan barang bukti berupa:

- 1 (satu) unit sepeda motor Yamaha Mio GT Warna merah Nopol H-5152-DH.

- STNK spm Yamaha Mio GT Warna merah Nopol H-5152-DH

- SIM C an. Haris Setyo Yunanto, Dikembalikan kepada terdakwa);

f. Membebankan biaya perkara kepada Terdakwa sebesar Rp.2.000,- ( dua ribu rupiah );

2. Putusan Pengadilan Negeri SEMARANG Nomor 625/Pid.B/2017/PN.Smg Tahun 2017

\footnotetext{
${ }^{5}$ HB. Sutopo, 2002, Pengantar Metodologi Penelitian, UNS Press. Surakarta, Hal 98
} 
Majelis Hakim menjatuhkan putusan pidana pada kasus nomor 625/Pid.B/2017/PN.Smg, adalah sebagai berikut:

a. Menyatakan Terdakwa Eko Budiyono Bin Amanto terbukti secara sah dan meyakinkan bersalah melakukan tindak pidana "mengemudikan kendaraan bermotor yang karena kelailaiannya mengakibatkan kecelakaan lalu lintas yang mengakibatkan korban meninggal dunia dan korban luka ringan dan kerusakan kendaraan dan atau barang.

b. Menjatuhkan pidana terhadap Terdakwa Eko Budiyono Bin Amanto oleh karena itu dengan pidana penjara selama : 3 (tiga) tahun, dan 6 (enam) bulan, pidana denda sebesar Rp.5.000.000,00 (lima juta rupiah), dengan ketentuan bila denda tersebut tidak dibayar maka diganti dengan penjara selama 3 (tiga) bulan kurungan.

c. Menetapkan masa penahanan yang telah dijalani terdakwa dikurangkan seluruhnya dari pidana yang dijatuhkan .

d. Memerintahkan agar Terdakwa tetap ditahan ;

e. Menetapkan barang bukti berupa;

f. Menyatakan barang bukti berupa:

- 1 (satu) unit Kbm Truck Dump Nissan No.Pol: H-1042-AW.

- 1 (satu) lembar STNK Kbm Truck Dump Nissan No.Pol: H-1042-AW.

- 1 (satu) lembar SIM B-II Umum an. EKO BUDIYONO. (Dikembalikan kepada Terdakwa EKO BUDIONO)

- 1 (satu) unit Kbm Lighttruck Mitsubishi No.Pol: H-1642-ZY.

- 1 (satu) lembar STNK Kbm Light Truck Mitsubishi No.Pol: H-1642-ZY

- 1 (satu) lembar SIM A an. Sunarto (Dikembalikan kepada saksi Sunarto)

- 1 (satu) unit Spm Yamaha Mio No.Pol: H-2718-CY

- 1 (satu) lembar STNK Spm Yamaha Mio No.Pol: H-2718-CY - 1 (satu) lembar SIM C an. SUYATNO (Dikembalikan kepada saksi Ari Yunianto)

- 1 (satu) unit Spm Honda Beat No.Pol: H-4188-ABD

- 1 (satu) lembar STNK Spm Honda Beat No.Pol: H-4188-ABD

- 1 (satu) lembar SIM C an. Rina Afriana Asih (Dikembalikan kepada orang tua Rina Afriana Asih (Alm))

- 1 (satu) unit Spm Yamaha Jupiter No.Pol: H-4930-VM

- 1 (satu) lembar STNK Spm Yamaha Jupiter No.Pol: H-4930-VM

- 1 (satu) lembar SIM C an. Imam Taufik (Dikembalikan kepada saksi Imam Taufik)

g. Menetapkan agar terdakwa dibebani membayar biaya perkara sebesar Rp. 2.000,- (Dua ribu rupiah);

\section{Penerapan pertanggungjawaban pidana terhadap kasus kelalaian yang menimbulkan kecelakaan sehingga korban meninggal dunia}

Pertanggungjawaban pidana apabila seseorang pelaku harus melakukan perbuatan pidana; mampu bertanggung jawab; dengan kesengajaan atau kealpaan, dan tidak adanya alasan pemaaf, ${ }^{6}$ pembahasan terkait unsur pertanggungjawaban pidana dalam kasus kelalaian pengemudi yang menyebabkan kecelakaan lalu lintas, adalah sebagai berikut:

1. Harus melakukan tindak pidana

Pertanggungjawaban pidana hanya dapat terjadi jika sebelumnya seseorang telah melakukan tindak pidana. Moeljatno mengatakan "orang tidak mungkin dipertanggung jawabkan (dijatuhi

\footnotetext{
${ }^{6}$ Roslan Saleh, 1982, Perbuatan Pidana dan Pertanggungjawaban Pidana, Jakarta: Aksara Baru, hal 75-76
} 
pidana) kalau dia tidak melakukan perbuatan pidana dilakukannya tindak pidana." ${ }^{7}$ Pertanggungjawaban pidana hanya akan terjadi jika sebelumnya telah ada seseorang yang melakukan tindak pidana.

Sebaliknya, eksistensi suatu tindak pidana tidak tergantung apakah ada orang yang pada kenyataannya melakukan tindak pidana tersebut. Berdasarkan putusan hakim tersebut maka bentuk pertanggungjawaban terdakwa terhadap kelalaian pengemudi bahwa pada kasus-kasus tersebut dengan terdakwa Haris Setyo Yunanto dan Eko Budiyono telah terbukti secara sah dan meyakinkan bersalah melakukan tindak pidana "mengemudikan kendaraan bermotor karena kelalaiannya mengakibatkan kecelakaan lalu lintas yang mengakibatkan orang lain mati“ dan menjatuhkan pidana kepada terdakwa Haris Setyo Yunanto oleh karena itu dengan pidana penjara selama 5 (lima) bulan dengan tuntutan jaksa adalah 8 (delapan) bulan penjara. Sedangkan kasus kedua dengan terdakwa Eko Budiyono dipidana 3 (tiga) tahun 6 (enam) bulan penjara, lebih berat dibandingkan kasus pertama karena dikasus kedua terdakwa terbukti juga menyebabkan orang meninggal, adanya korban luka ringan serta kerusakan barang.

Hal ini sudah sesuai dengan peraturan yang berlaku sebagaimana diatur dalam Pasal 193 ayat (1) KUHAP yang bunyinya sebagai berikut: "Jika pengadilan berpendapat bahwa terdakwa bersalah melakukan tindak pidana yang didakwakan kepadanya, maka pengadilan menjatukan pidana.

Kedua kasus tersebut pertanggungjawaban pidana yang diberikan telah memenuhi unsur pertanggungjawaban pidana yaitu harus melakukan tindak pidana, yaitu kecelakaan yang menyebabkan korban meninggal dunia, sehingga unsur ini terpenuhi. Putusan yang ditetapkan hakim masih berada di bawah dari Ketentuan Pasal 310 ayat (4) UU LLAJ yang menyatakan bahwa "Dalam hal kecelakaan sebagaimana dimaksud pada ayat (3) yang mengakibatkan orang lain meninggal dunia, dipidana dengan pidana penjara paling lama 6 (enam) tahun dan/atau denda paling banyak Rp 12.000.000,00 (dua belas juta rupiah)."

Dalam putusan pada Nomor 599/Pid.Sus/2017/PN.Smg dan Nomor 625/Pid.B/2017/PN.Smg, proses pengambilan keputusan yang dilakukan oleh Majelis Hakim menurut sudah sesuai dengan aturan hukum yang berlaku, yaitu berdasarkan pada sekurang-kurangya dua alat bukti yang sah, dimana dalam kasus tersebut, alat bukti yang digunakan hakim adalah keterangan saksi, barang bukti dan keterangan terdakwa. Lalu kemudian mempertimbangkan tentang pertanggungjawaban pidana, dalam hal ini Majelis Hakim berdasarkan fakta-fakta yang timbul di persidangan menilai bahwa terdakwa dapat dipertanggungjawabkan atas perbuatan yang dilakukan dengan pertimbangan bahwa pada saat melakukan perbuatannya terdakwa sadar akan akibat yang ditimbulkan, pelaku dalam melakukan perbuatannya berada pada kondisi yang sehat dan cakap untuk mempertimbangkan perbuatannya.

2. Mampu bertanggung jawab

Dari sudut kemampuan bertanggung jawab maka hanya seseorang yang mampu bertanggung jawab yang dapat dipertanggungjawab pidanakan. Dikatakan seseorang mampu bertanggung jawab, bilamana pada umumnya tidak terganggu keadaan jiwanya dan jiwanya mampu untuk dapat menginsyafi hakekat dari tindakanya dapat menentukan kehendaknya atas tindakan tersebut, apakah akan dilaksanakan atau tidak dan, dapat mengetahui ketercelaan dari tindakan tersebut" 8

Kemampuan bertanggung jawab dalam kasus tersebut adalah bahwa pada terdakwa telah memiliki SIM yaitu SIM C dan SIM BII, hal ini berarti bahwa terdakwa telah berusia 17 tahun ke atas,

\footnotetext{
${ }^{7}$ Moelyatno, 1987, Asas-Asas Hukum Pidana, Jakarta : Bina Aksara, hal 19.

${ }^{8}$ EY Kanter dan SR Sianturi, 2002 Asas-Asas Hukum Pidana di Indonesia, Jakarta : Storia Grafika, hal 249
} 
dimana usia tersebut merupakan usia yang secara hukum telah mampu bertanggung jawab atas perbuatannya.

Pasal 77 ayat [1] UULLAJ menyatakan bahwa fungsi dari penerbitan SIM adalah sebagai tanda bukti kompetensi bagi seseorang yang telah lulus uji pengetahuan, kemampuan, dan keterampilan untuk mengemudikan kendaraan bermotor di jalan sesuai dengan persyaratan yang ditentukan berdasarkan UULLAJ (Pasal 1 angka 4 Perkapolri No. 9 Tahun 2012 tentang Surat Izin Mengemudi). Berdasarkan penjelasan tersebut, dapat dikatakan bahwa tanggung jawab atas kecelakaan kendaraan bermotor adalah pada pengemudinya.

Dalam kedua kasus tersebut maka diketahui bahwa Terdakwa telah mampu bertanggung jawab, karena telah berusia lebih dari 17 tahun, sehingga secara umur Terdakwa telah mampu bertanggung jawab atas perbuatan yang dilakukkannya secara hukum, sehingga unsur pertanggungjawaban pidana yaitu mampu bertanggung jawab dalam hal ini terpenuhi.

3. Dengan kesengajaan atau kealpaan

Pada setiap kasus kecelakaan lalu lintas yang terjadi di jalan raya, tentunya mempunyai konsekuensi hukum bagi pengemudi kendaraan tersebut. Ketentuan hukum yang mengatur terkait kecelakaan maut yang mengakibatkan luka-luka ataupun meninggalnya seseorang, secara umum adalah KUHP (Kitab Undang-undang Hukum Pidana) dan secara khusus adalah diatur dalam Undang Undang (UU) No. 22 tahun 2009 tentang Lalu Lintas.

Sering kali masyarakat memandang bahwa kecelakaan lalu lintas yang menyebabkan lukaluka dan kematian, mutlak kesalahannya selalu pada pengemudi kendaraan yang bersangkutan. Sedangkan menurut teori hukum yang berlaku bahwa kesalahan seseorang dilihat dari faktor kejadian yang sebenarnya, faktor apa yang menyebabkan kecelakaan lalu lintas tersebut. Hal ini dapat diungkapkan dari kronologis kejadian, kesaksian-kesaksian termasuk saksi mata yang melihat terjadinya kecelakaan.

Dalam putusan pada 599/Pid.Sus/2017/PN.Smg dan Nomor 625/Pid.B/2017/PN.Smg tersebut pada dasarnya pengemudi tidak sengaja tetapi dalam hal ini pengemudi dinyatakan sebagai kealpaan, dan karena kealpaan dirinya yang menyebabkan korban meninggal dunia maka pengemudi kendaraan bermotor yang mengakibatkan kematian dalam kecelakaan lalu lintas dikenakan Pasal 359 KUHP, yang berbunyi: "Barang siapa karena kesalahannya (kealpaannya) menyebabkan orang lain mati, diancam dengan pidana penjara paling lama lima tahun atau pidana urungan paling lama satu tahun."

Dalam kasus pertama dan kedua maka hakim telah memutuskan bahwa terdakwa lalai sehingga menyebabkan kecelakaan sehingga korban meninggal dunia, berdasarkan hal tersebut maka unsur pertanggungjawaban pidana telah terpenuhi, kemudian dengan berdasar keempat unsur dalam Pasal 310 UU LLAJ tersebut, umumnya unsur ke (3) yang lebih memerlukan waktu agar dapat terbukti. Melalui penyidikan, aparat penegak hukum, dalam hal ini pihak kepolisian hendaklah harus membuktikan adanya unsur kelalaian itu.

Atas kedua aturan tersebut apabila dalam kasus kecelakaan tersebut mengakibatkan kematian bagi seseorang, maka menurut hukum yang harus dikenakan bagi pengemudi kendaraan tersebut adalah jeratan pidana yang diatur dalam UU LLAJ, dalam hal ini sesuai dengan ketentuan yang mengacu pada Pasal 63 ayat (2) KUHP menyebutkan bahwa"

Jika suatu perbuatan masuk dalam suatu aturan pidana yang umum, diatur pula dalam aturan pidana yang khusus, maka hanya yang khusus itulah yang diterapkan." Acuan dalam Pasal 63 ayat (2) KUHP tersebut, karena kasus kecelakaan lalu lintas yang mengakibatkan kematian telah diatur dalam UU LLAJ sebagai peraturan yang bersifat khusus, maka penuntut umum dalam surat 
dakwaannya dan Majelis Hakim dalam mengadili dengan menerapkan ketentuan dalam Pasal 310 ayat (4) UU LLAJ dengan ancaman pidana maksimum 6 (enam) tahun, dan bukan Pasal 359 dalam KUHP.

Dalam kedua kasus tersebut maka diketahui bahwa Terdakwa telah lalai sehingga dalam kasus kecelakaan tersebut menyebabkan korban meninggal dunia, hal ini unsur pertanggungjawaban pidana yaitu akibat kesejangajaan atau kealpaan dalam hal ini terpenuhi.

4. Tidak adanya alasan pemaaf

Dalam alasan pemaaf ini, seorang subyek pelaku tindak pidana dihadapkan pada suatu keadaan yang demikian rupa sehingga keadaan jiwanya menuntun ia untuk melakukan suatu tindakan yang termasuk dalam tindak pidana. Ini berarti dalam alasan pemaaf ini unsur kesalahan dari pelaku ditiadakan. Termasuk dalam alasan pemaaf tersebut adalah:

a. Ketidakmampuan bertanggungjawab dari pelaku (Pasal 44 ayat (1) KUHP)

b. Pembelaan terpaksa yang melampaui batas (pasal 49 ayat (2) KUHP)

c. Hal menjalankan dengan itikad baik, suatu perintah jabatan yang tidak sah (Pasal 51 auat (2) KUHP)

Dari kedua kasus tersebut menunjukkan bahwa pengemudi tidak melarikan diri untuk menghindari tanggung jawab tetapi pengemudi secara sadar menyatakan bahwa bersalah sehingga pengemudi terlebih dahulu berhenti dan menolong korban kecelakaan tesebut dan antara kedua belah pihak antara terdakwa dan keluarga korban telah terjadi kesepakatan damai.

Berdasarkan ketentuan di atas, dapat diketahui bahwa pada 599/Pid.Sus/2017/PN.Smg dan Nomor 625/Pid.B/2017/PN.Smg, walaupun pengemudi telah bertanggung jawab atas kematian korban, tuntutan pidana terhadap dirinya tidak menjadi hilang sehingga kedua Terdakwa tetap masih harus mempertanggungjawabkan perbuatan pidananya.

\section{Hambatan dalam Penerapan Pertanggungjawaban Pidana dalam Kasus Kelalaian}

Beberapa hambatan dalam penerapan pertanggungjawaban pidana terhadap kasus kelalaian pengemudi yang menimbulkan kecelakaan sehingga korban meninggal dunia adalah: ${ }^{9}$

1. Kurangnya saksi

Alat bukti disekitar TKP dan petunjuk-petunjuk lain kurang kuat untuk mengungkapkan suatu peristiwa kecelakaan yang mengakibatkan korbannya meninggal dunia. Dalam hal ini tidak ada saksi yang dapat dimintai keterangan, termasuk saksi korban yang telah meninggal dunia. Saksi merupakan kunci dari terjadinya suatu tindak pidana. Apabila saksi yang ditemukan hanya satu orang, hal ini juga masih merupakan kendala dalam pelaksanaan penyidikan. Hal ini disebabkan jumlah alat bukti harus lebih dari satu orang sesuai dengan pasal 183 KUHAP.

Kurangnya saksi memang bisa menghambat pertanggungjawaban pidana, hal ini karena saksi merupakan salah satu alat bukti, hal ini dikarenakan di jalan raya orang banyak yang lalu lalang sehingga setelah mengetahui ada kecelakaan terkadang masyarakat langsung pergi meninggalkan tempat, tanpa ingin menjadi saksi dalam kecelakaan lalu lintas tersebut.

2. Keterangan yang diberikan oleh para saksi, antara saksi yang satu dengan saksi yang lain tidak saling bersesuaian, hal ini membuat hakim harus benar-benar jeli dalam pengambilan keputusan, karena sudut pandang saksi dalam melihat kecelakaan tersebut terkadang memang mempunyai persepsi yang berbeda-beda sehingga terkadang keterangan saksi tidak sesuai antara satu dengan yang lain.

\footnotetext{
${ }^{9}$ Wawancara dengan Hakim Pengadilan Negeri Semarang, Suparno tanggal 3 Januari 2018
} 
3. Menentukan siapa yang benar-benar bersalah atau lalai dalam tindak pidana, misalnya menentukan siapa yang paling bersalah dalam hal kecelakaan antar mobil dengan motor, mobil dengan sepeda ontel, biasanya yang menyebabkan korban meninggal ditentukan sebagai pihak yang bersalah, hal ini dikarenakan hakim tidak melihat secara langsung kejadian tersebut dan hanya berdasarkan keterangan dari saksi ataupun terdakwa.

\section{Penegakan hukum pidana}

Dalam mengimpementasi penegakan hukum, ada tiga unsur yang selalu harus diperhatikan, yaitu : a) kepastian hukum bahwa terhadap pelanggar benar-benar ditindak, b) kemanfaatan, dari tindakan penegakan hukum yang dilakukan dapat memberikan efek prevensi, dan c) keadilan, apabila dari sisi korban masyarakat dan pelaku merasakan adanya kesebandingan antara perbuatan dan konsekuensi yang diterima oleh pelaku dan korban.

Dilihat dari ketiga prinsip dalam penegakan hukum tersebut, penegakan hukum terhadap tindak pidana lalu lintas jalan raya boleh dikatakan masih jauh dari yang diharapkan. Terbukti dari data yang telah dipaparkan pada bagian sebelumnya, yang intinya bahwa dari sisi kepastian hukum tingkat pengungkapan terhadap pelaku tindak pidana lalu lintas masih sangat rendah. Sementara dari sisi kemanfaatan, tidak banyak efek prefensi dari penegakan hukum yang dilakukan selama ini. Buktinya di tengah-tengah masyarakat masih saja banyak terjadi berbagai bentuk tindak pidana lalu lintas jalan raya. Sedangkan dari sisi keadilan juga masih belum banyak dirasakan adanya putusan hakim terhadap pelaku tindak pidana lalu lintas dirasakan sebagai perwujudan rasa keadilan, baik bagi korban maupun bagi masyarakat umum.

Sehubungan dengan penegakan hukum ini, Soerjono Soekanto menyatakan bahwa masalah pokok dalam penegakan hukum sebenarnya terletak pada faktor-faktor yang mempengaruhi. Faktorfaktor tersebut yaitu: a) factor perundang-undangan, b) faktor penegak hukum, c) factor fasilitas penegakan hukum, d) faktor masyarakat, dan e) faktor budaya. ${ }^{10}$

Penegakan hukum jika ditinjau dari salah satu factor di atas, seperti faktor Perundang-undangan, yaitu sebagai berikut ada beragam jenis tindak pidana lalu lintas sebagaimana telah dikemukakan sebelumnya, jika disimak dalam KUHP, ternyata telah didapati pengaturannya, sebagaimana diatur dalam:

\section{Pasal 359:}

Menyebutkan barang siapa karena kekhilafannya menyebabkan orang mati, dipidana dengan pidana penjara selama-lamanya lima tahun atau pidana kurungan selama-lamanya satu tahun.

Pasal 360 ayat 1:

Menyebutkan barang siapa karena kekhilafannya menyebabkan orang luka berat dipidana dengan pidana penjara selama-lamanya lima tahun atau pidana kurungan selama-lamanya satu tahun.

Pasal 360 ayat 2:

Menyatakan barang siapa karena kekhilafannya menyebabkan orang luka sedemikian rupa sehingga orang itu menjadi sakit sementara atau tidak dapat menjalankan jabatan atau pekerjaannya sementara dipidana dengan pidana penjara selama-lamanya sembilan bulan atau dipidana dengan pidana kurungan selama-lamanya enam bulan atau pidana denda setinggitingginya empat ribu lima ratus rupiah.

Pasal 361:

Jika kejahatan yang dituangkan dalam bab ini dilakukan dalam menjalankan sesuatu jabatan atau pekerjaan, maka pidana itu boleh ditambah sepertiganya, dan dapat dijatuhkan pencabutan hak

\footnotetext{
${ }^{10}$ Soerjono Soekanto, Aspek Sosio Yuridis Masyarakat. Penerbit Alumni Bandung, 1983, hal. 130
} 
melakukan pekerjaan, yang dipergunakan untuk menjalankan kejahatan itu, dan hakim dapat memerintahkan pengumuman putusannya.

Sejumlah ketentuan yang menyangkut tindak pidana lalu lintas secara normatif masih ditemui beberapa kelemahan. Pertama, kecuali pasal tentang tindak pidana lalu lintas semuanya bersifat interpretatif, sehingga dapat mengakibatkan disparitas dalam penerapannya. Kedua, sanksi pidana yang diancamkan kurang berat sehingga dianggap tidak responsif terhadap reaksi masyarakat terhadap tindak pidana lalu lintas.

Berkaitan dengan masalah rendahnya pidana yang dijatuhkan terhadap pelaku tindak pidana lalu lintas secara normatif dapat dijelaskan, bahwa pertama, berkaitan dengan maksimal pidana yang diancamkan memang relatif rendah. Mulai dari satu tahun sampai dengan lima tahun. Apalagi terhadap pidana alternatif berupa denda, nominalnya jauh lebih rendah dengan perkembangan nilai mata uang untuk kondisi sekarang.

Kedua, dilihat dari konstruksi pasal dan system pengancaman. Seperti dimaklumi bersama, sampai saat ini landasan hukum dalam menjaring pelaku tindak pidana lalu lintas masih tergantung dengan KUHP warisan Pemerintah Kolonial Belanda, yang berlaku sejak tahun 1918. Dalam KUHP ini sistem pengancaman pidana yang digunakan adalah General Straft maksimal selama 20 tahun, general straft minimal selama satu hari, dan special straft maksimal sesuai dengan masing-masing jenis tindak pidana. Tanpa dilengkapi dengan special straft minimal. Dengan system yang semacam itu maka hakim diberi kebebasan untuk menjatuhkan pidana serendah mungkin, asal tidak kurang dari satu hari. Konsekuensi pertama hakim bebas menjatuhkan pidana yang sangat ringan. Kedua, terjadi disparitas yang tajam dalam kasus sejenis.

\section{PENUTUP}

\section{Kesimpulan}

Penegakan hukum pidana yang ditinjau dari factor perundang-undangan pada kasus tindak pidana kecelakaan lalu lintas yang menyebabkan hilangnya nyawa orang pada tindak pidana kecelakaan lalu lintas di Kota Semarang masih memiliki beberapa kelemahan, seperti bersifat interpretatif, sehingga dapat mengakibatkan disparitas dalam penerapannya, serta sanksi pidana yang diancamkan kurang berat sehingga dianggap tidak responsive.

Pertanggungjawaban pada kasus tindak pidana kecelakaan lalu lintas yang menyebabkan hilangnya nyawa orang pada tindak pidana kecelakaan lalu lintas di Kota Semarang pada kasus dalam studi ini telah memenuhi unsur-unsur pertanggungjawaban pidana secara umum yaitu harus melakukan perbuatan pidana, mampu bertanggung jawab, dengan kesengajaan atau kealpaan, dan tidak adanya alasan pemaaf.

\section{Saran}

Dalam rangka perbaikan akan kelemahan yang masih muncul dalam penegakan hukum dalam kasus tindak pidana kecelakaan lalu lintas yang menyebabkan hilangnya nyawa orang pada tindak pidana kecelakaan lalu lintas, para penegak hukum diharapkan untuk lebih tinggi dalam menetapkan dan lebih mempertimbangaknd alam memberikan pidana alternatif berupa denda, nominalnya harus disesuaikan dengan bentuk kerugian yang ditimbulkan dan sesuai dengan perkembangan nilai mata uang untuk kondisi sekarang. 


\section{DAFTAR PUSTAKA}

Bambang Poernomo, 2001, Kapita Selekta Sistem Peradilan Pidana, Universitas Jayabaya, Jakarta.

EY Kanter dan SR Sianturi, 2002, Asas-Asas Hukum Pidana di Indonesia, Storia Grafika, Jakarta.

Barda Nawawi Arief, 1996, Bunga Rampai Kebijakan Hukum Pidana, PT. Citra Aditya Abadi, Jakarta.

Deny Irwanto, 2017, Angka Kecelakaan Lalu Lintas di Kota Semarang Menurun, https://www.beritasemarang.net/tahun-2017-angka-kecelakaan-lalu-lintas-di-kota-semarangmenurun/4893/, diakses 3 Januari 2018

Mahkamah Agung RI, Direktori Putusan, https://putusan.mahkamahagung.go.id/pengadilan/pnsemarang/direktori/pidana-umum/lalu-lintas, diakses 3 Januari 2018

HB. Sutopo, 2002, Pengantar Metodologi Penelitian, UNS Press. Surakarta.

Roslan Saleh, 1982, Perbuatan Pidana dan Pertanggungjawaban Pidana, Aksara Baru, Jakarta.

Moelyatno, 1987, Asas-Asas Hukum Pidana, Bina Aksara, Jakarta. 